\title{
Linking Entrepreneurial Intentions and Mindset Models: A Comparative Study of Public and Private Universities in Vietnam
}

\author{
Viet Quoc Cao, ${ }^{a^{*}}$ and Tien Thanb Thi Ngo ${ }^{\mathrm{b}}$ \\ ${ }^{a}$ University of Economics Ho Chi Minh City, Vietnam \\ ${ }^{\mathrm{b}}$ Ho Chi Minh City Cadre Academy, Vietnam
}

\begin{abstract}
The main purpose of our study is to test the mindset model explored by Mathisen and Arnulf (2013). Based on Ajzen's theory of planned behavior, the capacity theory, and the need for achievement theory, an extension model on the entrepreneurial intentions involving implementing mindset and elaborating mindset has been proposed. These constructs were confirmed in the proposed research model, including the need for achievement, perceived educational support, perceived structural support, perceived relational support and entrepreneurial intentions. The moderating role of gender, Grade Point Average (GPA) and the type of university were also tested. Research findings support that the need for achievement has a significant impact on the students' mindsets and their entrepreneurial intentions. Elaborating the mindset, implementing the mindset and the perceived relational support significantly affect entrepreneurial intentions. The findings have contributed new ideas to the theoretical framework of entrepreneurship. They confirm the importance of the need for achievement in the relationship between the mindset and the entrepreneurial intentions of business students.
\end{abstract}

Key words: elaborating mindset; implementing mindset; entrepreneurial intentions; need for achievement

JEL classification: M1

* Corresponding author's e-mail: vietcq@ueh.edu.vn 


\section{Introduction}

Over the past few years, entrepreneurship has played a major role in encouraging economic development, reducing unemployment and helping social development (Sesen 2013). Researchers from many different countries have become increasingly interested in doing more thorough studies about students' entrepreneurial intentions. Ngô and Cao (2016) suggest three paths for researchers to follow, in an effort to track down the factors influencing students' entrepreneurial intentions.

The first path is to examine the learners' assessments of each curriculum they are taking and its relationship to their entrepreneurial intentions. Bae et al. (2014) divide business education into two distinct branches of perception: a perceived entrepreneurship education and a perceived general business education. The second path is to research the environmental factors such as the educational environment, social capital and the extent of the families' support. The third path is to research the learners themselves, in terms of their characteristics, behavior, and mindset.

On the basis of a new concept introduced and validated by Mathisen and Arnulf (2013), our study focuses on the relationship between the entrepreneurship mindset and other typical factors: the perceived university environment, the perceived relationship environment, the perceived structural environment and the need for achievement and the students' entrepreneurial intentions.

However, it seems that there has been no further research verifying the entrepreneurship mindset's construct since the suggestion of Mathisen and Arnulf (2013).
Also, according to Gilliam and Voss (2013), the evaluation of the validity of a new construct needs to be performed within a nomological validity network (i.e., the new construct needs to be tested for its relationship with some similar constructs). More specifically, Mathisen and Arnulf (2013) merely assessed the content and distinctions between the implementing mindsets and the elaborating mindsets, but did not consider them within the same construct, such as entrepreneurial intentions. This consideration is of great importance when these implementing mindsets and elaborating mindsets are independent and different components. Thus, we review these elements in a theoretical framework relating to the factors affecting the entrepreneurial intentions of students.

On the other hand, factors such as the need for achievement, perceived structural environment and support (i.e., family, friends) and the published findings of different authors are contradictory and inconsistent (e.g., Pruett et al. 2009; Turker and Selcuk 2009); Schwarz et al (2009). Hence, a more thorough verification of the relationships between these factors, as well as more extensive research on the influence of the implementing mindset and elaborating mindset would be interesting and worthy of note.

This study aims to assess the distinctions between the implementing and elaborating mindsets and entrepreneurial intentions, while exploring the relationship of the mindsets (i.e., implementing and elaborating) with the need for achievement and entrepreneurial intentions, evaluating both the influence of the university environment, social and economic policies and support (i.e., family and friends) on the stu- 
dents' entrepreneurial intentions, with reference to their gender, Grade Point Average - GPA (of ten according to Vietnam's education system) and the type of university they attend.

The Vietnamese context was chosen for several reasons. After the reunification in 1975, the Vietnamese government instituted a command economy, in which all businesses are state-owned. In the late 2000s, Vietnam transformed into a mixed economy with the privatisation of many state-owned enterprises. An entrepreneurial education program was encouraged by the government. There were only a few surveys of entrepreneurial intentions in Vietnam. The intention to start a business was evaluated through a survey with 2,000 participants answering questionnaires regarding their intention to launch a start-up within the next three years. The data indicated that the percentage of people having entrepreneurial intentions amounted to 18 percent of those surveyed, which was 6 percent lower than that of the year 2013 and ranked fourth among other countries in the same region, after the Philippines, Indonesia, and Thailand (Luong et al. 2014). The survey presented assessments of the motivation of entrepreneurs in the Vietnamese context: almost 30 percent said they had no better career choices than entrepreneurship while 70 percent said they recognised opportunities to undertake new ventures.

This research is composed of five parts. The first part presents the literature review and the research model. The second part details the method of our research. We describe the sample and the measures in this part. Next, we show the test results of the research model, including the measurement model and structural model. The fourth part compares and discusses our findings. The conclusion is presented in the final part.

\section{Literature Review}

\section{Entrepreneurial Intentions}

Grounded in the Theory of Planned Behavior (TPB), human intentions are determined by indicators such as the Subjective Norm (SN) and the Personal Attitude (PA) (Ajzen 1991). This model was first employed to measure the intentions for entrepreneurship by Krueger and Carsrud (1993). Engle et al. (2010:52) concluded that 'Ajzen's model does appear to be an important cognitive process model for the evaluation of entrepreneurial intent'. According to the model, a Behavioral Intent (BI) is defined as a measurement of the strength of the intention to perform a specific behavior (Fishbein and Ajzen, 1975). Within the context of entrepreneurship, Entrepreneurial Intentions (EIs) replace BI. Entrepreneurial intentions are considered to be a perceptive target along the way to becoming an entrepreneur (Wilson et al. 2007). An individual's intention to start a business comes from their realisation of opportunities, the use of available resources and the support of the environment to create their own business (Kuckertz and Wagner 2010). When applied to a student, it refers to the intent of a student to start a new business.

\section{Entrepreneurial Mindsets}

Based on the capacity theory of Teece (2010), Mathisen and Arnulf (2013) remarked that the core of the theory is that only effort or enthusiastic concentration are decisive, not the analytic usage of knowledge. This theory is used to deduce 
a definition of the entrepreneurship mindset -an interesting examination of the relationship between the careful thinking, calculation, decisiveness and doubts of entrepreneurs. A conclusion drawn by Mathisen's group, from the previous studies, suggested that a mindset could be described as having flexible strategies, which evolve or change in harmony with the individuals' interactions and their experiences from the surrounding environment. These authors claimed that opportunities for selfemployment are always available and can be found and seized upon in the market. However, some opportunities need to be created. A capacity to recognise business opportunities is key to the identification of the possibilities for entrepreneurship (Baron and Ensley, 2006). Thus, opportunities for a start-up exist everywhere, all the time, but whether an individual can seize them or not depends on their ability. Liñan and Fayolle (2015) summarised that the formation of entrepreneurial intentions and the changing psychological process from intention to behavior cannot ignore the evaluation of mental prototypes and cognitive scripts. We call this process a mindset. Mathisen and Arnulf (2013) distinguish the differing mindsets by basing them on factors regarding a person's behavior: a mindset is an instinctive reflex, a product of the experiences of solving existing problems. Also, a mindset is described not only as a stimulating interaction but also as adapting to the environment in a way that conscious and considerate efforts can be taken advantage of. The authors reckon that the particular characteristics of a mindset are in a constant state of change and development in an interactive relationship between mindsets and their environment.

\section{Table 1. Comparison of the construct of IMs and EIs}

EIs construct (Liñán and Chen 2009; Sesen 2013; Yurtkoru et al. 2014).

\section{IMs construct}

(Mathisen and Arnulf 2013: 136)

I am determined to create a firm in the future (EI1)

I have very seriously thought of starting a firm (EI2)

I will make every effort to start and run my own firm (EI3)

I bave the firm intention to start a firm someday (EI4)

I am ready to do anything to be an entrepreneur (EIS)

My professional goal is to become an entrepreneur (EI6)
When I think of my idea for a start-up, I'm determined to start my own business. (IM1) I decided to start my own business. (IM2) I plan on how to start my own business (IM3) I have a plan about when to start my own business (IM4)

When I recognize an opportunity, I will evaluate the opportunity and start my business (IM5) 
In the context of entrepreneurship, Mathisen's group categorise the entrepreneurial mindsets into two components: (1) elaborating mindsets and (2) implementing mindsets. Elaborating mindsets are a necessary condition and a prerequisite for the actual act of establishing a new business. The greater the elaborating mindset one has, the lower the possibility of their making a decision is. Therefore, they suggest and prove that an elaborating mindset has no relation with the behavior towards entrepreneurship, while people with an implementing mindset are inclined to think hard and be aware when starting up a business. So, in other words, their thoughts are more likely to turn into actual actions.

An implementing mindset is defined as the thinking process required for identifying targets, setting out strategies or plans and then specifying the steps to achieve the objectives (Mathisen and Arnulf 2013). The authors propose that implementing mindsets have a positive impact on the establishment of a new business by an entrepreneur.

An effort to analyse and evaluate Mathisen and Arnulf's (2013) work has led us to this study. The key point is recognized, but there is an overlap of the notion of Implementing Mindsets (IMs) and Entrepreneurial Intentions (EIs). As shown in Table 1, we compare the content of the two constructs. It is possible to see a partial overlap in both the face and content values, which may occur in some observable variables.

Upon our analysing the face and the validity of the content of the constructs, it is possible to acknowledge that the IMs construct is different from the concept of the EIs in the first part of each statement; the second part of each statement has nearly the same meaning. Therefore, it would be likely that the two variables would re-enter into a construct.

Mathisen's group used a dependent variable for starting a business's behavior, measured by the number of companies established by each student at three levels: (1) zero - no company was established; (2) one or two companies were created and (3) three or more companies were created. In the context of Norway, before graduation, students can easily open one or more businesses of their own. However, it may not be the case in Vietnam and other countries. That is why there is no point in relying on this dependent variable. In other words, if the EIs construct is employed, it is likely that these two constructs partially overlap. However, when the content validity above is taken into consideration, it is clear that the construct of the implementing entrepreneurial mindset has a distinctive character. In addition, in terms of meaning, it expresses determination and careful planning in the minds of those with IMs involved in entrepreneurial activities. Furthermore, McGrath and MacMillan (2000) recommend that entrepreneurial mindsets include the capacity to quickly detect, act and assemble a business team that under questionable conditions. But the elaborating mindsets' entrepreneurs will consider their opportunities from the aspects of their financial commitment, time and information (both negative and positive).

They will think carefully about the dimensions of the intent to start a business. We believe that entrepreneurs have both elaborating mindsets and implementing mindsets. When an entrepreneur finds a gap in the market, he or she will set a goal 
of establishing a business. The entrepreneurs will find many ways to handle valuable opportunities. On the one hand, they may consider their capacities. On the other hand, they make a plan related to their business. Thus, the following hypotheses are formulated:

H1: Elaborating mindsets (Elas) have a positive impact on Entrepreneurial intentions (EIs).

H2: Implementing mindsets (IMs) have a positive impact on Entrepreneurial intentions (EIs).

\section{The Need for Achievement (NACs)}

As early as the 1960s, Davis and McClelland (1962) mentioned the need for achievement as one of the driving forces that plays a decisive role in economic growth and recession. The authors argued that NACs are also a fundamental motivator of entrepreneurial and technical innovations. An individual with a higher need for achievement appreciates the personal responsibility, prefers solving problems unassisted, likes taking acceptable risks and has a keen interest in the outcomes of his/ her efforts or decisions (Sesen 2013).

The need for achievement could influence the entrepreneurial process and the creation of new businesses (Brandstätter 2011; Arasteh et al. 2012). Ghasemi et al. (2011) showed a positive relationship between the need for achievement and entrepreneurial intentions. However, the study by Sesen (2013) did not reveal a lack of statistical evidence to confirm the relationship between Turkish students' entrepreneurial intentions and their need for achievement. Such inconsistency possibly provides the reason for our re-examination of this relationship in the Vietnamese context.

According to the basics of the NACs theory, an individual with NACs would demonstrate a determination to orient his/ her effort to a goal or a specific task, ' $A$ person with high need for achievement is "more self-confident, enjoys taking carefully calculated risks, researches his environment actively, and is very much interested in concrete measures of how well he is doing"'. (Kristiansen and Indarti 2004:59). Therefore, it is our strong belief that NACs also has a positive effect on IMs and Elas in the context of a business start-up. The hypotheses are proposed as follows:

H3: Need for achievement (NACs) bave a positive effect on implementing mindsets (IMs)

H4: Need for achievement (NACs) have a positive effect on Elaborating mindsets (Elas)

H5: Need for achievement (NACs) have a positive effect on Entrepreneurial intentions (EIs)

\section{Perceived Educational Support (PESs), Perceived Structural Support (PSSs)}

Based on the theory of planned behavior, the elements of the environmental group (education, economy, law) act as social norms and these factors have positive impacts on entrepreneurial intentions (Autio et al. 2001). Turker and Selcuk (2009) confirmed this relationship in a study conducted in Turkey. However, the results of Schwarz et al. (2009) did not provide statistical evidence to support these hypotheses. These inconsistencies seem to provide the opportunity for our research 
to confirm the relationships in a new context. We propose more hypotheses, as follows:

H6: There is a positive relationship between Perceived educational support (PESs) and Entrepreneurial intentions (EIs).

H7: There is a positive relationship between Perceived structural support (PSSs) and Entrepreneurial intentions (EIs).

Perceived relational support (PRSs) was measured and evaluated by Turker and Selcuk (2009) using two observable variables -the role of family and friends in support of an individual's business initiation. This construct was derived from Henderson and Robertson (2000), which confirmed that the family was the second most important factor that influenced the career choice of students. Thus, Turker and Selcuk (2009) proposed and validated the relationship between PRSs and EIs. However, the authors did not find statistical evidence for this relationship. Meanwhile, Pruett et al. (2009) demonstrated that family support has a positive impact on EIs. Thus, we propose Hypothesis 8:

H8: There is a positive relationship between Perceived relational support (PRSs) and Entrepreneurial intentions (EIs).

Finally, some control variables such as gender, Grade Point Average (GPA) and the type of university would make the research complete. In Vietnam's education system, there are some differences between public and private universities, in their quality and infrastructure. Although the Ministry of Education controls their programs and curricula, the private universities are more dynamic. The facilities in private universities are often more spacious and mod-

Figure 1. Proposed Research Model

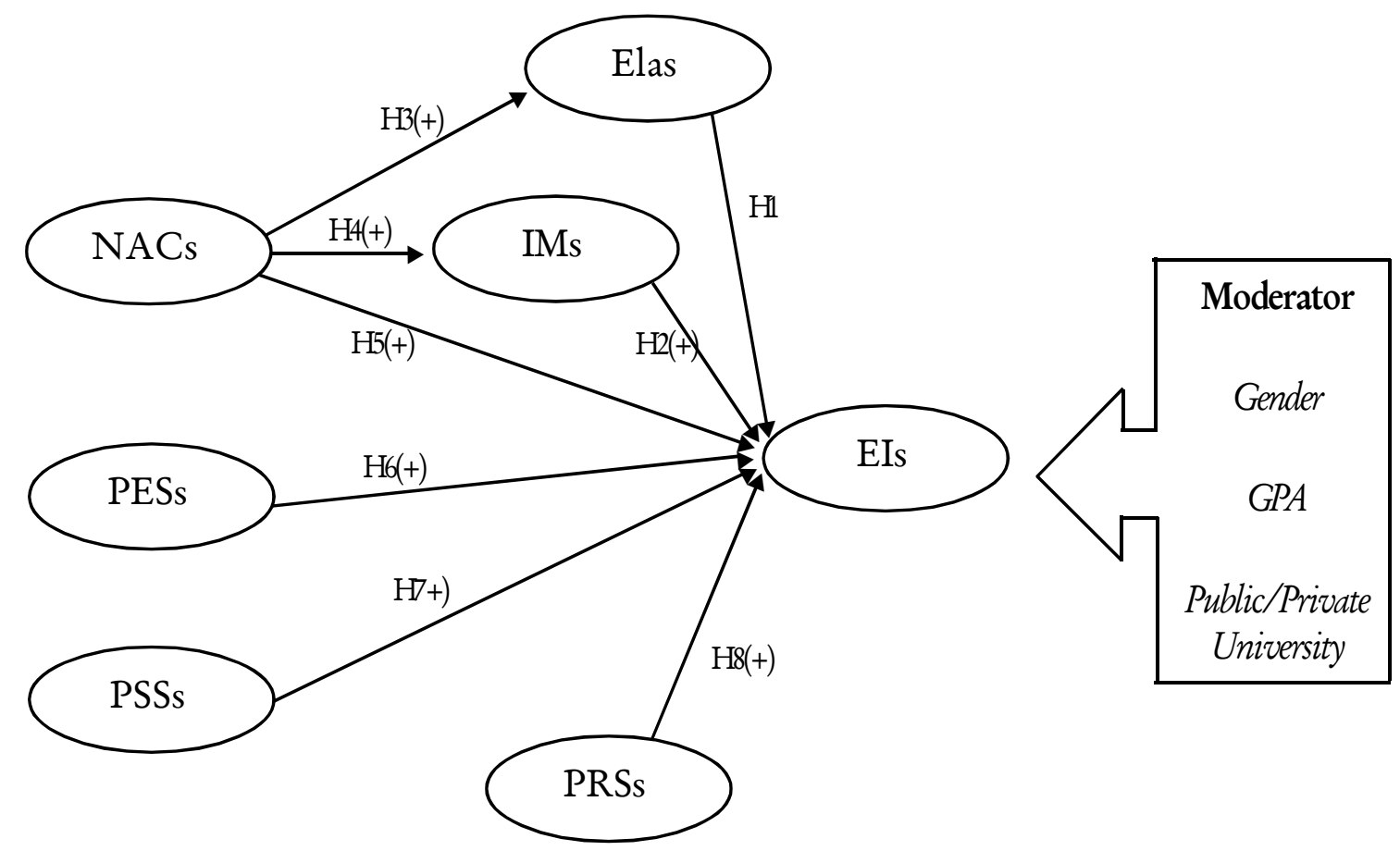


ern than those found in public ones. The leaders of the private schools have total control over decisions about the replacement, repair, upgrading or construction of new buildings for learning. Private universities do not receive financial support from the state; their financial resources are from the tuition fees of the students studying at them, or from customers and donations. Tuition fees at these schools tend to be much higher than those of the public universities. In order to attract more students, so they can increase their competitiveness with the public schools, private universities, in addition to their more modern facilities, also try to change the curriculum in a more realistic way. Many private schools also create a training system linked with foreign universities and colleges, to help students get an international degree. Thus, the hypotheses of the moderating roles of this variable are stated:

H9: There are differences in the relationships of variables between (1) male and female groups, (2) low and high GPA groups, and (3) public and private universities groups.

\section{Methods}

\section{Sample}

We prepared 1,000 questionnaires. The overall response rate was more than 80 percent ( 820 responses). After checking and selecting the data, we deleted 154 incomplete questionnaires. The final sample of 666 undergraduate students came from the business administration programs of four different universities in Ho Chi Minh City (two public and two private universities) (see Table 2).

\section{Measures}

We used a five-point Likert scale (one $=$ strongly disagree to five $=$ strongly agree) for all the items. Elas (Elaborating Mindsets) and IMs (Implementing Mindsets) were measured employing the test instruments developed by Mathisen and Arnulf (2013). NACs (Need for Achievement) was taken from Kristiansen and Indarti (2004). PESs (Perceived Educational Support), PSSs (Perceived Structural Support), and PRSs (Perceived Relational

Table 2. Descriptive Statistics

\begin{tabular}{lccccc}
\hline & Frequency & Percent & $\begin{array}{c}\text { Valid } \\
\text { (Percent) }\end{array}$ & $\begin{array}{c}\text { Cumulative } \\
\text { (Percent) }\end{array}$ & $\begin{array}{c}\text { GPA mean } \\
\text { score }\end{array}$ \\
\hline Male & 212 & 31.8 & 31.8 & 31.8 & 7.1 \\
Female & 454 & 68.2 & 68.2 & 100.0 & 7.2 \\
Total & 666 & 100.0 & 100.0 & & \\
Public University & 443 & 66.5 & 66.5 & 66.5 & 7.4 \\
Private University & 223 & 33.5 & 33.5 & 100.0 & 6.7 \\
Total & 666 & 100.0 & 100.0 & & \\
\hline
\end{tabular}


Support) came from Turker and Selcuk (2009). EIs (Entrepreneurial Intentions) was measured by Sesen (2013).

\section{Results}

\section{Descriptive Results}

Table 2 shows the descriptive statistics of the 666 university students who responded to the questions in the survey $(212$ males $-31.8 \%$, 454 females - 68.2\%). We also asked the GPA of each student (maximum of ten points in the Vietnamese education system). The GPA of the male students was equal to that of the female students in public universities. However, the GPA of two public university students was higher than that gained by the private university students.

\section{Measurement Model Testing}

Principal axis factoring and the promax rotation were used to conduct the factor analysis. Table 3 reported six factors, including the independent variables and the dependent variable (the EIs). All the factor loadings were between 0.46 and 0.90 . Several items (ex., IM1, IM5, EI4, EI5 and EI6) were deleted from the analysis because they showed poor measurement properties). The Cronbach's alpha reliability of all the scales was larger than 0.7 , which confirmed the internal consistency of each construct. Also, we followed the instruction of
Nunnally and Bernstein (1994); the PSSs were deleted because of the poor reliability of Cronbach's alpha (0.32).

As presented in the literature review, it is believed that there were some issues related to the face validity and content validity of the EIs construct and IMs construct. Factor analysis results proved that not all the items of EIs and IMs in the research would be kept.

\section{Confirmatory Factor Analysis (CFA)}

As shown in Table 3, the composite reliability (suggested by Fornell and Larcker 1981), each of which ranged from 0.7 to 0.8 was also calculated. For the validity, both the convergent and discriminant in the CFA were tested. Figure 2 shows that all the factor loadings exceeded 0.5 and they were statistically significant at the p-value of 0.05 (Hair et al., 2014). The average variance extracted was between 0.4 and 0.6 (see Table 3), meaning that the convergent validity of all the scales was acceptable. We checked our measurement model with some goodness-of-fit measures, including chi-square, the Goodness of Fit Index (GFI), the Tucker-Lewis Index (TLI), the Comparative Fit Index (CFI), and the Root Mean Square-Error of Approximation (RMSEA), suggested by Bentler (2007). All the indexes were high (ex., chi-square $=$ $361.698(\mathrm{p}=0.000)$; GFI $=0.945$; $\mathrm{TLI}=$ 0.921; CFI $=0.937$; RMSEA $=0.05$ ). 
Table 3. Factor Analysis, Reliability, Composite Reliability and Average Variance Extracted

\begin{tabular}{|c|c|c|c|c|c|c|}
\hline \multirow{2}{*}{ Code } & \multirow{2}{*}{ Items } & \multicolumn{5}{|c|}{ Factor } \\
\hline & & Elas & IMs & PESs & NACs EIs & PRSs \\
\hline Ela3 & $\begin{array}{l}\text { I am considering whether I have the } \\
\text { opportunity financially to become engaged } \\
\text { in entrepreneurial activities. }\end{array}$ & 0.82 & & & & \\
\hline Ela4 & $\begin{array}{l}\text { I consider whether the timing to start my } \\
\text { own business is right. }\end{array}$ & 0.75 & & & & \\
\hline Ela2 & $\begin{array}{l}\text { I am considering whether I have the time to } \\
\text { become engaged in entrepreneurial activities }\end{array}$ & 0.72 & & & & \\
\hline Ela5 & $\begin{array}{l}\text { I am looking for negative and positive } \\
\text { information about becoming engaged in } \\
\text { entrepreneurial activities. }\end{array}$ & 0.53 & & & & \\
\hline Ela1 & $\begin{array}{l}\text { I am considering both the positive and } \\
\text { negative aspects of becoming engaged in } \\
\text { entrepreneurial activities. }\end{array}$ & 0.46 & & & & \\
\hline IM3 & $\begin{array}{l}\text { I have a plan/strategy for how to start my } \\
\text { own business. }\end{array}$ & & 0.90 & & & \\
\hline IM4 & $\begin{array}{l}\text { I have a plan/strategy for when to start my } \\
\text { own business. }\end{array}$ & & 0.75 & & & \\
\hline IM2 & I have decided to start my own business. & & 0.48 & & & \\
\hline PES3 & $\begin{array}{l}\text { My university develops my entrepreneurial } \\
\text { skills and abilities. }\end{array}$ & & & 0.74 & & \\
\hline PES2 & $\begin{array}{l}\text { My university provides the necessary } \\
\text { knowledge about entrepreneurship. }\end{array}$ & & & 0.70 & & \\
\hline PES1 & $\begin{array}{l}\text { The education I receive in my university } \\
\text { encourages me to develop creative ideas for } \\
\text { being an entrepreneur. }\end{array}$ & & & 0.59 & & \\
\hline NAC2 & $\begin{array}{l}\text { I will try hard to improve on past work } \\
\text { performance. }\end{array}$ & & & & 0.69 & \\
\hline NAC3 & $\begin{array}{l}\text { I will seek extra responsibilities in jobs } \\
\text { assigned to me. }\end{array}$ & & & & 0.63 & \\
\hline NAC1 & $\begin{array}{l}\text { I will do very well in fairly difficult tasks } \\
\text { relating to my studies and my work. }\end{array}$ & & & & 0.56 & \\
\hline
\end{tabular}


Gadjah Mada International Journal of Business - May-August, Vol. 21, No. 2, 2019

Table 3. Continued

\begin{tabular}{|c|c|c|c|c|c|c|c|}
\hline \multirow{2}{*}{ Code } & \multirow{2}{*}{ Items } & \multicolumn{6}{|c|}{ Factor } \\
\hline & & Elas & IMs & PESs & NACs & EIs & PRSs \\
\hline NAC4 & I will try to perform better than my friends. & & & & 0.51 & & \\
\hline EI2 & $\begin{array}{l}\text { I have very seriously thought of starting a } \\
\text { firm. }\end{array}$ & & & & & 0.83 & \\
\hline EI3 & $\begin{array}{l}\text { I will make every effort to start and run my } \\
\text { own firm. }\end{array}$ & & & & & 0.63 & \\
\hline EI1 & $\begin{array}{l}\text { I am determined to create a firm in the } \\
\text { future. }\end{array}$ & & & & & 0.60 & \\
\hline PRS2 & $\begin{array}{l}\text { If I decide to be an entrepreneur, my friends } \\
\text { will support me. }\end{array}$ & & & & & & 0.87 \\
\hline PRS1 & $\begin{array}{l}\text { If I decide to be an entrepreneur, my family } \\
\text { members will support me. }\end{array}$ & & & & & & 0.55 \\
\hline Cronbac & ch's alpha & 0.8 & 0.8 & 0.7 & 0.7 & 0.7 & 0.7 \\
\hline Composi & ite Reliability (CR) & 0.8 & 0.8 & 0.7 & 0.7 & 0.7 & 0.7 \\
\hline Average & Variance Explained (AVE) & 0.4 & 0.6 & 0.5 & 0.4 & 0.5 & 0.5 \\
\hline
\end{tabular}


Figure 2. CFA Results

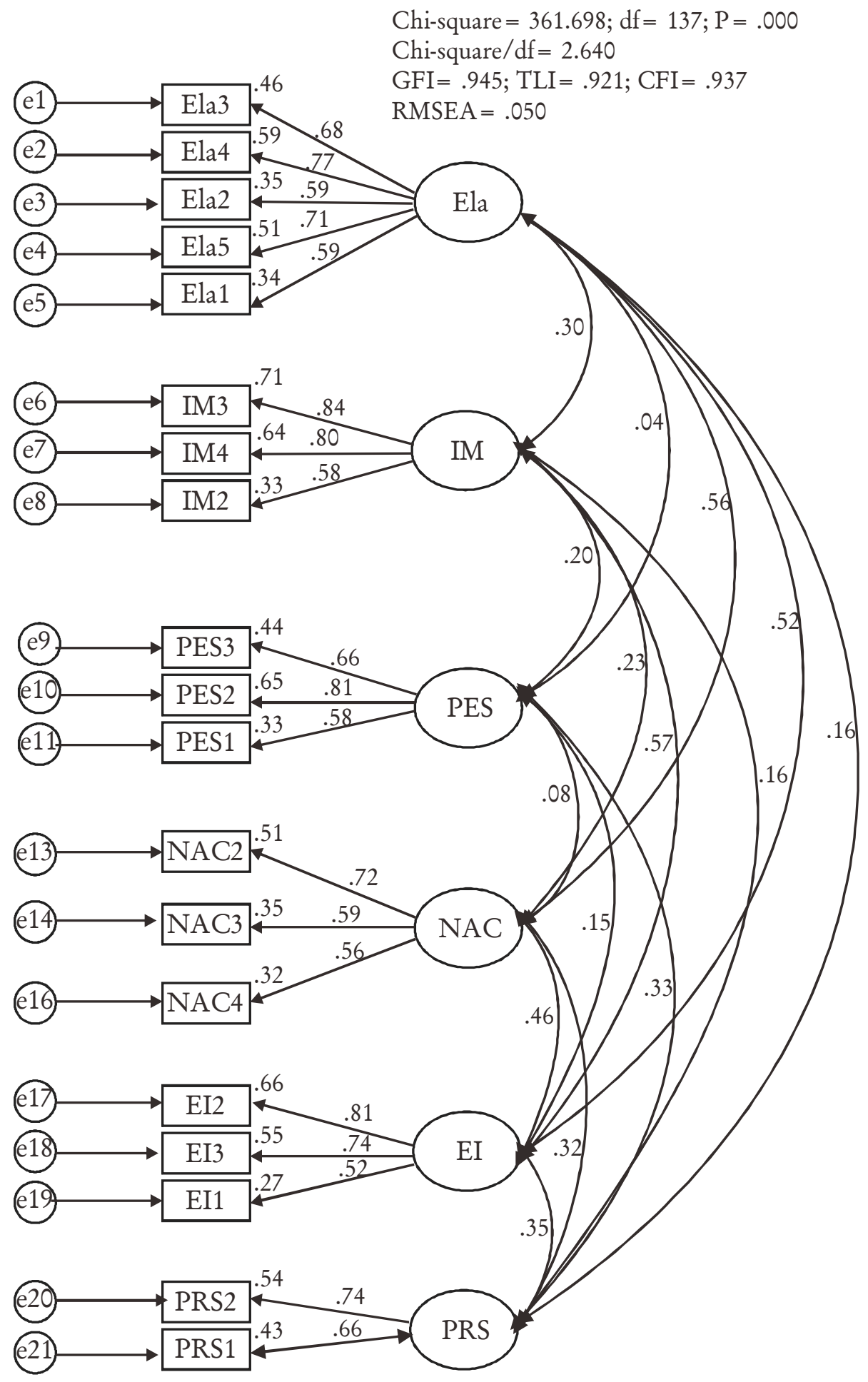




\section{Research Model Testing}

We estimated the research model by conducting a SEM analysis. Figure 3 showed a good fit for the model, with chisquare $=390.876, \mathrm{GFI}=0.942, \mathrm{TLI}=$ $0.916, \mathrm{CFI}=0.93$, $\mathrm{RMSEA}=0.051)$.
As shown in Table 4, elaborating mindsets had a positive impact on entrepreneurial intentions (beta $=0.29, \mathrm{p}<0.001$ ). Implementing mindsets were found to have a positive effect on entrepreneurial intentions (beta $=0.43, \mathrm{p}<0.001)$. Need for achievement was found to have a positive

Figure 3. SEM results
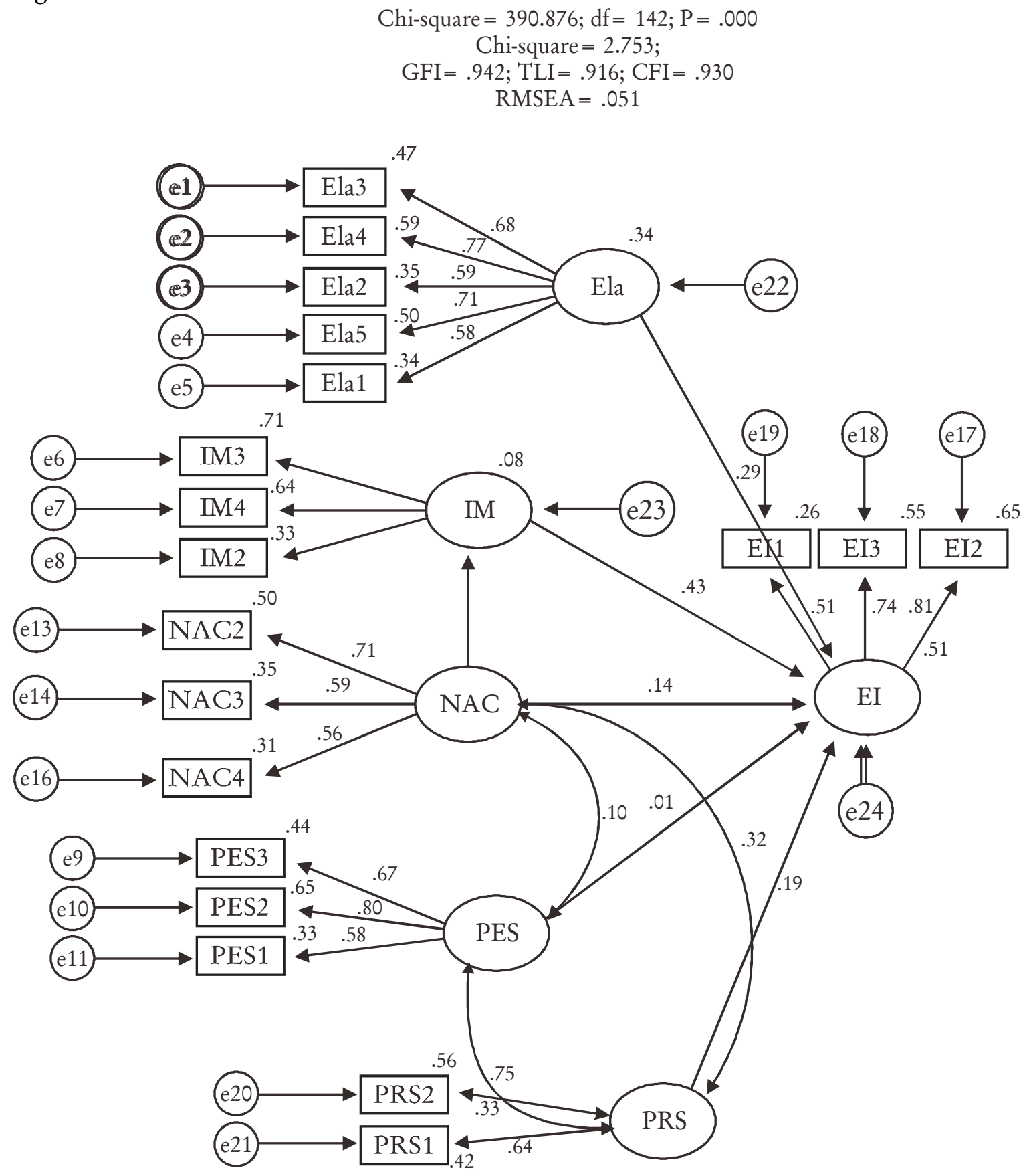
impact on elaborating mindsets (beta = $0.58, \mathrm{p}<0.001)$. Need for achievement positively predicted implementing mindsets (beta $=0.29, \mathrm{p}<0.001$ ) and entrepreneurial intentions (beta $=0.14, \mathrm{p}<0.05$ ). In addition, it is proved that perceived relational support positively predicted entrepreneurial intentions (beta $=0.19, \mathrm{p}<$ 0.001 ). Thus, hypotheses $1,2,3,4,5$, and 8 were fully supported. Perceived educational support did not have a positive effect on entrepreneurial intentions (beta $=$ -0.01, p > 0.05).

The moderating role of gender, GPA, and the type of university were also tested. As shown in Table 5, the results of the moderation test proved that gender and GPA did not moderate all the relationships in our research model (chi-square's difference for male/female $=12.677, \mathrm{df}=7, \mathrm{p}$ $>0.05$; chi-square's difference for GPA < $7.0 />7.0=8.102, \mathrm{df}=7, \mathrm{p}>0.05)$. How- ever, the moderating role of public/private universities (chi-square's difference $=$ 21.773, df $=7, \mathrm{p}<0.05$ ) was worthy of note. (See Table 5. Multi-group analysis).

In sum, these findings indicated that the relationships between (1) the need for achievement and implementing mindsets, (2) the need for achievement and elaborating mindsets, (3) elaborating mindsets and entrepreneurial intentions, (4) implementing mindsets and entrepreneurial intentions, (5) the need for achievement and entrepreneurial intentions, (6) perceived educational support and entrepreneurial intentions and (7) perceived relational support and entrepreneurial intentions were the same for gender (male and female) and GPA (lower 7.0 and higher 7.0). However, a difference existed between public universities and private universities. As shown in Table 6, the difference was found in the relationship between (1) the need for

\section{Table 4. Hypotheses Testing}

\begin{tabular}{ccccc}
\hline Hypotheses & Relationship & $\begin{array}{c}\text { Standardized } \\
\text { Regression } \\
\text { Weights (beta) }\end{array}$ & P - value & Conclusions \\
\hline H1 & Elas $\rightarrow$ EIs & 0.29 & $* * *$ & Accept \\
H2 & IMs $\rightarrow$ EIs & 0.43 & $* * *$ & Accept \\
H3 & NACs $\rightarrow$ Elas & 0.58 & $* * *$ & Accept \\
H4 & NACs $\rightarrow$ IMs & 0.29 & $* * *$ & Accept \\
H5 & NACs $\rightarrow$ EIs & 0.14 & 0.035 & Accept \\
H6 & PESs $\rightarrow$ EIs & -0.01 & 0.812 & Reject \\
H7 & PSSs $\rightarrow$ EIs & & & Reject $(*)$ \\
H8 & PRSs $\rightarrow$ EIs & 0.19 & $* * *$ & Accept \\
\hline
\end{tabular}


Gadjah Mada International Journal of Business - May-August, Vol. 21, No. 2, 2019

achievement and entrepreneurial intentions and (2) perceived relational support and entrepreneurial intentions. These relationships were not significant $(p>0.05)$ for the public university group whereas they were significant $(p<0.05)$ in the private university group.

\section{Table 5. Multi-group Analysis}

\begin{tabular}{lccccc}
\hline \multicolumn{5}{c}{ Male/Female } \\
\hline Overall Model & $\chi^{2}$ & df & P value & TLI & CFI \\
Unconstrained & 568.403 & 284 & 0.000 & 0.906 & 0.922 \\
Fully constrained & 581.08 & 291 & 0.000 & 0.906 & 0.92 \\
Difference & 12.677 & 7 & 0.08 & 0 & -0.002 \\
\hline \multicolumn{7}{c}{ GPA $<7.0$ and $>7.0$} \\
\hline Unconstrained & 637.528 & 284 & 0.000 & 0.906 & 0.922 \\
Fully constrained & 645.63 & 291 & 0.000 & 0.908 & 0.922 \\
Difference & 8.102 & 7 & 0.324 & 0.002 & 0 \\
\hline & Public/Private University & & \\
\hline Unconstrained & 619.328 & 284 & 0.000 & 0.894 & 0.912 \\
Fully constrained & 641.101 & 291 & 0.000 & 0.892 & 0.908 \\
Difference & 21.773 & 7 & 0.003 & -0.002 & -0.004 \\
\hline
\end{tabular}

Table 6. Relationship Comparison

\begin{tabular}{lcccccccc}
\hline \multirow{2}{*}{ Relationship } & \multicolumn{3}{c}{ Public Universities } & \multicolumn{3}{c}{ Private Universities } \\
\cline { 2 - 9 } & beta & S.E. & C.R. & $P$ & beta & S.E. & C.R. & $P$ \\
\hline NACs $\rightarrow$ IMs & 0.63 & 0.13 & 4.89 & $* * *$ & 0.39 & 0.15 & 2.58 & 0.01 \\
NACs $\rightarrow$ Elas & 0.72 & 0.09 & 7.73 & $* * *$ & 0.63 & 0.13 & 5.03 & $* * *$ \\
Elas $\rightarrow$ EIs & 0.46 & 0.12 & 3.78 & $* * *$ & 0.3 & 0.09 & 3.35 & $* * *$ \\
IMs $\rightarrow$ EIs & 0.47 & 0.05 & 8.72 & $* * *$ & 0.13 & 0.05 & 2.61 & 0.009 \\
NACs $\rightarrow$ EIs & 0.27 & 0.17 & 1.61 & 0.108 & 0.28 & 0.12 & 2.31 & 0.021 \\
PESs $\rightarrow$ EIs & -0.03 & 0.08 & -.41 & 0.68 & -0.01 & 0.07 & -0.2 & 0.845 \\
PRSs $\rightarrow$ EIs & 0.1 & 0.08 & 1.24 & 0.214 & 0.37 & 0.1 & 3.73 & $* \% *$ \\
\hline
\end{tabular}




\section{Discussion}

The findings of the study, with a sample size of 666 respondents, have identified four variables that had positive effects on the students' EIs (i.e. Elas, IMs, NACs, and PRSs). The study also found a positive relationship between IMs and EIs. This result supports the proposition of Mathisen and Arnulf (2013), which is that there is a positive correlation between high intensity implemental thoughts and entrepreneurial activities.

Similarly, the study found a positive relationship between NACs and EI. This result is consistent with the studies of Brandstätter (2011), Ghasemi et al. (2011) and Arasteh et al. (2012), meaning that the more individuals need achievement, the more likely they are to start a business.

The study also showed that PRSs were positively associated with EI. This agrees with the study of Turker and Selcuk (2009), which confirms that families and friendships were the important factors that influenced the career choices of students. We found a new relationship between the implementing mindsets and entrepreneurial intentions.

\section{Conclusion}

The contribution of our study is to test how different the mindsets' construct (i.e., implementing mindsets, elaborating mindsets) and entrepreneurial intentions probably are. The exploratory task into the relationship between the need for achievement, implementing mindsets, elaborating mindsets, and entrepreneurial intentions revealed a positive impact of the elaborating mindsets on entrepreneurial intentions. It is implied that the greater the elaborating mindsets the students have, the more entrepreneurial intentions they will show. Furthermore, this study found that the implementing mindsets created a positive effect on entrepreneurial intentions. Thus, it appears that mindsets have a significant role in business. In other words, the degree programs or the course syllabuses should serve this purpose - they are presumably embedded with specific activities for the students to foster their mindsets' capacity.

In addition, it is obvious that the need for achievement of the students influences their mindsets and their entrepreneurial intentions. Educators and curricula designers should make deliberate efforts to promote the need for achievement in students' minds via the courses taught at the universities. Another finding is that the PESs did not have a negative effect on EIs. This is mainly due to the fact that universities in Vietnam tend to create tradition-based curricula with business and management programs in them, and most teaching, learning, and testing activities are centering on such predominant assumptions.

In a nutshell, the entrepreneurial implication is that entrepreneurship training programs in universities are absolutely vital to enhancing their students' initiatives in business start-ups after graduation. Opportunities to meet with many successful entrepreneurs and gain experience from them would be an undeniable benefit to the students and only after attending relevant and highly applicable courses can students take the initiative with their careers and entrepreneurial actions. The courses themselves provide business planning knowledge for young entrepreneurs and build entrepreneurial confidence for students who are starting a business. An understanding of how entrepreneurial mindsets are 
formed and how entrepreneurs' intend to build their start-ups may be of considerable value. Entrepreneurial educational policymakers can benefit if they create policies that are perceived to influence the students' mindsets and intentions.

This study also has certain limitations. First, due to a shortage of time, the researchers did not manage to select a greater number of subjects to meet the requirement of a large sample size. Those who were chosen, from four universities in Ho Chi Minh City, could not represent the whole population of Vietnamese university students.

Second, entrepreneurial activities and the challenges that business owners may have to cope with differ from region to re- gion; thus, cultural practices and specific markets play a role in shaping entrepreneurial activities. More precisely, the survey, which was only conducted in a single region, seems not to reach definite and conclusive findings.

Therefore, future research should be done with an increased sample size with various characteristics: the sampling task should cover students in the South, Central and North of Vietnam. Moreover, future studies should carefully investigate the cultural factors and entrepreneurship education for entrepreneurial intentions. More specifically, researchers could make a further examination into other elements to see whether passion, enthusiasm, and emotion influence entrepreneurial intentions.

\section{Reference}

Ajzen, I., 1991. The theory of planned behaviour. Organizational Behaviour and Human Decision Processes 50 (2): 179-211. Available at: < http://linkinghub.elsevier.com/retrieve/pii/ 074959789190020T >.

Arasteh, H., T. Enayati, F. Zameni, and A. Khademloo. 2012. Entrepreneurial personality characteristics of university students: A case study. Procedia - Social and Behavioral Sciences 46: 5736-5740. Available at: <http://dx.doi.org/10.1016/j.sbspro.2012.06.507>.

Autio, E., H. Keeley, M. Klofsten, G. G. C. Parker, and M. Hay. 2001. Entrepreneurial intent among students in Scandinavia and in the USA. Enterprise and Innovation Management Studies 2 (2): 145-160. Available at: <http://papers.ssrn.com/sol3/ papers.cfm?abstract_id $=1875081>$.

Bae, T. J., S. Qian, C. Miao, and J. O. Fiet. 2014. The relationship between entrepreneurship education and entrepreneurial intentions: A meta-analytic review. Entrepreneurship: Theory and Practice 38 (2): 217-254.

Baron, R. A. and M. D. Ensley. 2006. Opportunity recognition as the detection of meaningful patterns: Evidence from comparisons of novice and experienced entrepreneurs. Management Science 52 (9): 1331-1344. Available at: < http://pubsonline.informs.org/doi/abs/10.1287/ mnsc. $1060.0538>$.

Bentler, P. M. 2007. On tests and indices for evaluating structural models. Personality and Individual Differences 42 (5): 825-829.

Brandstätter, H. 2011. Personality aspects of entrepreneurship: A look at five meta-analyses. Personality and Individual Differences 51 (3): 222-230. 
Davis, R. C., and D. C. McClelland. 1962. The achieving society. Technology and Culture 3 (3): 351. Available at: $<$ http://www.jstor.org/stable/3100843?origin $=$ crossref $>$.

Fishbein, M., and I. Ajzen. 1975. Belief formation. In Belief, Attitude, Intention, and Behavior: An Introduction to Theory and Research. Reading, MA: Addison-Wesley.

Fornell, C., and D. F. Larcker. 1981. Evaluating structural equation models with unobservable variables and measurement error. Journal of Marketing Research 18 (1): 39. Available at: $<$ http://www.jstor.org/stable/3151312?origin $=$ crossref $>$.

Ghasemi, F., A. Rastegar, R. G. Jahromi, and R. R. Marvdashti. 2011. The relationship between creativity and achievement motivation with high school students' entrepreneurship. Procedia - Social and Behavioral Sciences 30: 1291-1296. Available at: <http://dx.doi.org/10.1016/ j.sbspro.2011.10.250>.

Gilliam, D. A. and K. Voss. 2013. A proposed procedure for construct definition in marketing. European Journal of Marketing 47 (1/2): 5-26. Available at: < http:// www.emeraldinsight.com/doi/abs/10.1108/03090561311285439>.

Hair, J. F., W. C. Black, B. J. Babin, and R. E. Anderson. 2014. Multivariate Data Analysis (ed. $\left.7^{\text {th }}\right)$. Essex: Prentice-Hall, Inc., Pearson Education Limited.

Henderson, R., and M. Robertson. 2000. Who wants to be an entrepreneur? Young adult attitudes to entrepreneurship as a career. Career Development International 5 (6): 279-287.

Huan, L. M., Hang, P. T. T., Hai, L. T., Nga, D. T., and Quyen, D. T. 2014. Global Entrepreneurship Monitor Vietnam Report 2014. Hanoi. Available at: <http:// www.gemconsortium.org/report/49171>.

Kristiansen, S., and N. Indarti. 2004. Entrepreneurial intention among Indonesian and Norwegian students. Journal of Enterprising Culture 12 (01): 55-78. Available at: < http:// www.worldscientific.com/doi/abs/10.1142/S021849580400004X>.

Krueger, N. F., and A. L. Carsrud. 1993. Entrepreneurial intentions: Applying the theory of planned behaviour. Entrepreneurship \& Regional Development 5 (4): 315-330. Available at: < http://www.tandfonline.com/doi/abs/10.1080/08985629300000020>.

Kuckertz, A., and M. Wagner. 2010. The influence of sustainability orientation on entrepreneurial intentions - Investigating the role of business experience. Journal of Business Venturing 25 (5): 524-539. Available at: < http://dx.doi.org/10.1016/j.jbusvent.2009.09.001> .

Liñán, F., and Y. W. Chen. 2009. Development and cross-cultural application of a specific instrument to measure entrepreneurial intentions. Entrepreneurship: Theory and Practice, 33 (3): 593-617.

Mathisen, J. E., and J. K. Arnulf. 2013. Competing mindsets in entrepreneurship: The cost of doubt. International Journal of Management Education 11 (3): 132-141. Available at: < http:/ /dx.doi.org/10.1016/j.ijme.2013.03.003>.

McGrath, R., and I. C. MacMillan. 2000. The Entrepreneurial Mindset: Strategies for Continuously Creating Opportunity in an Age of Uncertainty. Cambridge: Harvard Business School.

Ngô, Tt. T., and Q. V. Cao. 2016. TÕng quan lý thuy ¿̇t vÁ ý ðЁnh khßi nghiÇp cça sinh viên. Tip chi Khoa hÍc (Đi híc Mß TpHCM) 5 (50): xxx.

Nunnally, J., and I. Bernstein. 1994. Psychometric Theory (3 $3^{\text {rd }}$ ed.). New York: McGraw - Hill. Available at: < http://rds.epi-ucsf.org > [Accessed 28 Nov. 2014]. 
Gadjah Mada International Journal of Business - May-August, Vol. 21, No. 2, 2019

Pruett, M., R. Shinnar, B. Toney, F. Llopis, and J. Fox. 2009. Explaining entrepreneurial intentions of university students: a cross-cultural study. International Journal of Entrepreneurial Behaviour and Research 15 (6): 571-594.

Schwarz, E. J., M. A. Wdowiak, D. A. Almer-Jarz, and R. J. Breitenecker. 2009. The effects of attitudes and perceived environment conditions on students' entrepreneurial intent: An Austrian perspective. Education + Training 51 (4): 272-291.

Sesen, H., 2013. Personality or environment? A comprehensive study on the entrepreneurial intentions of university students. Education + Training 55 (7): 624-640. Available at: < http:/ /www.emeraldinsight.com/10.1108/ET-05-2012-0059>.

Teece, D. J. 2010. Alfred Chandler and 'capabilities' theories of strategy and management. Industrial and Corporate Change 19 (2): 297-316.

Turker, D., and S. S. Selcuk. 2009. Which factors affect entrepreneurial intention of university students? Journal of European Industrial Training 33 (2): 142-159.

Wilson, F., J. Kickul, and D. Marlino. 2007. Gender, entrepreneurial self-efficacy, and entrepreneurial career intentions: Implications for entrepreneurship education. Entrepreneurship Theory and Practice 31 (3): 387-406. Available at: < http://doi.wiley.com/10.1111/j.15406520.2007.00179.x $>$.

Yurtkoru, E. S., Z. K. Kuscu, and A. Doganay. 2014. Exploring the antecedents of entrepreneurial intention on Turkish University students. Procedia-Social and Behavioral Sciences 150: 841850. 